\title{
17 地域医療および院内情報通信用マイクロ波無線と光テレメータシステムの開発研究
}

藤正 巌 (東京大医用電子, 東京大先端科学技術研), 井街 宏 (東京大医用電子)

目的 : 在宅医療ネットワークや院内の情報ネットワ 一クに扔いて, 電話やマイクロ波無線の果す役割は将 来非常に大きくなると予測される. 本研究においては, 2 力所の研究所間を電話とマイクロ波無線で結合し, 相互に情報を交換し合う手法を開発し，その実用性を 検討することを通じて, 将来の地域医療におけるネッ トワークメディアの有用性を検討することを目指した. 方法 : 基本ネットワークを東京大学先端研(駒場)と 東京大学医学部医用電子研(本郷)の間の $50 \mathrm{GHz}$ マイ クロウェーブネットワークで構築した． 2 研究所間は 直視できないため，中継点としてアークヒルズを利用 した. 両端及び中継点（3つのネットワークノード） にはTVビデオカメラ，大型TVモニタを用意した. 3 カ所のネットワークノードは静止画 TV 電話を設置 し，これにそれぞれマイクロコンピュータを接続した。 1 台の移動体通信用電話も用意しこれも静止画テレ ビ電話とコンピュータを接続した. 先端研と医用電子
研の電話回線にはリモートスイッチャーが付けられ， 人工心臟制御装置などにコンピュータを介して接続さ れた.

結果：実験は次のような状況妾設定して行われた。

(1) 2 研究所間の ON-LINE 動画像通信と, 相互の 装置のリモート切換及びリモート信号の読み取り。(2) 中継点でのセミナーや会議における TV ネットワーク の実用性の検討. (3)移動体 (携带用テレビ電話, 新型 のポケットベルを含む) からの 2 研究所との静止画ア クセスの有用性の検討とリモート装置操作の実用性の 検討.

考察：いずれの状況での実験も, 実用性は十分に認 められた．特にマイクロ波無線による相互交信は，先 端研オープンハウス, アーク都市塾でのリモートレク チャ一, 実験中の相互での装置切換に大きく役立つこ とがわかりこの方法の有用性を多く人に知らしめた.

\section{8 自作のイオントフォレーシス麻酔器による甲状腺穿刺吸引細胞診}

佐々木 純，斉藤和好 (岩手医大第 1 外科), 松谷裕之 (和賀診療所), 潼健治 (岩手医大救急センター)

日的: 最近, 甲状腺穿刺吸引細胞診が繁用されるよ うになったが，この診断法は穿刺する甲状腺の附近に 気管や頸動脈があり，しかも穿刺針にピストン運動を させるので患者に恐怖感と苦痛を与える. そこでわれ われは局所皮膚をイオントフォレーシス麻酔後穿刺し， 好結果を得ているので紹介する.

方法 : イオントフォレーシス麻酔とは局所麻酔剤を イオン化して微弱直流電流により経皮的に体内に浸透 させる方法である.われわれが自作した麻酔器は 30 volt 電池を用いて, 従来より大きな電流を流すように なっている. 取り扱いを簡単にするために麻醉器の外
側が陰極をかね, 片腕を麻酔器本体の山みにはめ, 電 流による障碍を広い皮膚面に分散させて，より大きな 電流に耐えられるようにしている，陽極は麻酔剤を小 さい面積に集中させるために，值径 $1.5 \mathrm{~cm}$ の小さな 金属円板を用いている. 陽極板の先に麻酔剂を滲み込 ませた綿塊をはめ, 前頸部皮膚に固定する，麻配剂と して $4 \%$ 塩酸キシロカインを用いる. 以上の装置と麻 酔剤により 30 volt, $1.5 \mathrm{~mA}, 5$ 分間の通電で充分な 麻酔ができる。

成績 : これまで 225 例の甲状腺穿刺吸引細胞診をこ の麻酔法により,ほとんど苦痛なく行い得た。 